\title{
Timber-colonizing gram-negative bacteria as potential causative agents of respiratory diseases in woodworkers
}

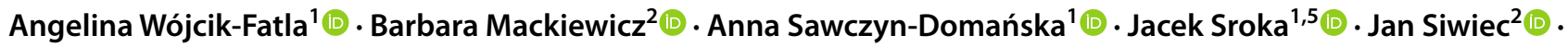

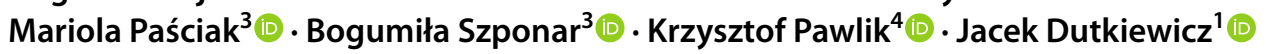

Received: 18 October 2021 / Accepted: 27 December 2021 / Published online: 11 January 2022

(c) The Author(s) 2022

\begin{abstract}
Occurrence Gram-negative bacteria occur commonly in the inner tissues of stored coniferous and deciduous timber, showing a marked variation in numbers. The greatest maximal numbers are found in the sapwood of coniferous timber. The common constituents of the Gram-negative biota are potentially pathogenic species of Enterobacteriaceae family of the genera Rahnella, Pantoea, Enterobacter, and Klebsiella. The air of wood-processing facilities is polluted with the wood-borne Gram-negative bacteria and produced by them endotoxin, as demonstrated worldwide by numerous studies.

Effects There are three potential pathways of the pathogenic impact of wood-borne Gram-negative bacteria on exposed woodworkers: allergic, immunotoxic, and infectious. Allergic impact has been underestimated for a long time with relation to Gram-negative bacteria. Hopefully, the recent demonstration of the first documented case of hypersensitivity pneumonitis (HP) in woodworkers caused by Pantoea agglomerans which developed in extremely large quantities in birch sapwood, would speed up finding of new wood-related cases of HP caused by Gram-negative bacteria. The second pathway is associated with endotoxin, exerting strong immunotoxic (excessively immunostimulative) action. It has been demonstrated that endotoxin is released into wood dust in the form of nano-sized microvesicles, by peeling off the outer membrane of bacteria. Endotoxin microvesicles are easily inhaled by humans together with dust because of small dimensions and aerodynamic shape. Afterwards, they cause a nonspecific activation of lung macrophages, which release numerous inflammatory mediators causing an inflammatory lung reaction, chest tightness, fever, gas exchange disorders, and bronchospasm, without radiographic changes. The resulting disease is known as "Organic Dust Toxic Syndrome" or "toxic pneumonitis." The potential third pathway of pathogenic impact is infection. The suspected species is Klebsiella pneumoniae that may occur commonly in wood dust; however, until now this pathway has not been confirmed.

Conclusion Summarizing, Gram-negative bacteria-inhabiting timber should be considered, besides filamentous fungi and actinobacteria, as important risk factors of occupational disease in woodworkers that could be either HP with allergenic background or toxic pneumonitis elicited by endotoxin.
\end{abstract}

Keywords Occupational health · Wood dust · Gram-negative bacteria $\cdot$ Hypersensitivity pneumonitis $\cdot$ Endotoxin . Microvesicles $\cdot$ Toxic pneumonitis $\cdot$ Pantoea agglomerans $\cdot$ Rahnella

Angelina Wójcik-Fatla

afatla@poczta.onet.pl; fatla.angelina@imw.lublin.pl

1 Department of Health Biohazards and Parasitology, Institute of Rural Health, Jaczewskiego 2, 20-090 Lublin, Poland

2 Department of Pneumology, Oncology and Allergology, Medical University of Lublin, Lublin, Poland

3 Department of Immunology of Infectious Diseases, Hirszfeld Institute of Immunology and Experimental Therapy, Polish Academy of Sciences, Wrocław, Poland
4 Department of Microbiology, Hirszfeld Institute of Immunology and Experimental Therapy, Polish Academy of Sciences, Wrocław, Poland

5 Department of Parasitology and Invasive Diseases, National Veterinary Research Institute, Puławy, Poland 


\section{Introduction}

Millions of people worldwide are exposed every day to the inhalation of wood dust (IARC 2016). This group includes workers employed at processing of wood in industrial premises (sawmills, plywood and chipboard factories, paper mills, wood pellet production facilities), craftsmen (joiners, carpenters), individuals occasionally exposed to wood (for example at house renovation) and those composting wood or using wood chips as a biofuel or bedding for animals.

Wood dust released into air of breathing zone during industrial processing of timber may contain large amounts of microorganisms developing in bark or in inner wood tissues: sapwood and heartwood. When inhaled by exposed woodworkers, they may initiate pathologic reactions in the lungs, leading to diseases like hypersensitivity pneumonitis (HP, extrinsic allergic alveolitis) or organic dust toxic syndrome (ODTS, toxic pneumonitis) (Eduard et al. 1994; Selman et al. 2012; Nogueira et al. 2019). Filamentous fungi (mostly of the genera Aspergillus, Penicillium and Rhizopus) have been identified as the most common cause of these diseases (NIOSH 1987; Færden et al. 2014; Nogueira et al. 2019), followed by actinobacteria (NIOSH 1987). Occupational diseases in woodworkers could be also elicited by the action of the constituents of wood itself, such as terpenes or plicatic acid causing asthma (Chan-Yeung 1994; Demers et al. 2000) or so far not identified constituents causing nasal adenocarcinoma (IARC 2016; Siew et al. 2017).

For a long time, Gram-negative bacteria have not been identified as causative agents of the occupational respiratory disease in woodworkers despite their abundant occurrence in inner wood tissues (Dutkiewicz et al. 1992a), and the presence of endotoxin in the air of wood industry facilities polluted with wood dust (Wilhelmsson et al. 1984; Asgedom et al. 2020). The situation changed when Mackiewicz et al. (2019) described for the first time the series of HP cases in woodworkers caused by a ubiquitous Gram-negative bacterium Pantoea agglomerans. The results of that study prompted us to prepare a review in a broader perspective, summarizing the current knowledge on the occurrence of Gram-negative bacteria in various woods and their potential pathogenic effects.

\section{Gram-negative bacteria in various woods and wood-processing facilities}

\section{Ecology}

Studies conducted in the second half of twentieth century demonstrated the presence of bacteria in wood tissues, both in the central, dead heartwood and in the peripheral live sapwood conducting water and nutrients (Greaves 1971; Rossell et al. 1973; Liese 1975). Their presence was detected in standing (live) trees but rather in low levels (Prażmo and Dutkiewicz 2000). The exception are some pathologic conditions such as "wetwood," characterized by the presence a water-soaked tissue colonized by bacteria, often Gram negative (Enterobacter, Pantoea, Pseudomonas) in the central core of the heartwood of some deciduous trees (elms, poplars, willows, maples, birches) (Murdoch and Campana 1983; Scott 1984; Prażmo et al. 1996).

Much more bacteria have been found in timber logs stored in lumber yards or in forest. Bacteria, including Gram-negative species, are regarded as early colonizers of stored timber (Greaves 1971; Rossell et al. 1973), preceding the growth of wood-rotting filamentous fungi, causing rapid decay of wood. Bacteria themselves are also able to decompose wood tissues. According to Singh et al. (2016) Gram-negative bacteria can degrade the walls of wood cells by two processes described as "tunneling" and "erosion."

\section{Levels of gram-negative bacteria in stored timber, commonest genera, levels of endotoxin}

At first, the studies on bacteria in wood were only qualitative, until an introduction of special wood-grinding drills enabled quantitative determination of microorganisms by culture per weight unit of wood. Recently the application of molecular methods increased an accuracy of taxonomic identification of bacteria (Johnston et al. 2016) but had not provided a sufficient solution for reliable quantitative measurements.

Table 1 presents the results of the studies performed in the years 1989-2000 on Gram-negative bacteria colonizing timber logs stored in lumber yards and forests near sawmills in Poland and USA, as potential sources of airborne contamination in wood-processing facilities. Wood samples were taken from transverse sections of the logs with an original, manually operated drilling device [U.S. Patent 5,078,553 assigned Jan. 7, 1992] that collects the pulverized wood into a flask attached beneath the bit in a one-step sterile process (Dutkiewicz et al. 1989). This approach provided a reliable insight into bacterial biota of various woods as a potential respiratory hazard for woodworkers.

The presence of Gram-negative bacteria was detected in the inner tissues of 12 kinds of stored coniferous and deciduous timber logs out of 14 examined. The concentrations of Gram-negative bacteria showed a marked variation, ranging from 0.0 to $6.05 \times 10^{9} \mathrm{CFU} \mathrm{g}^{-1}$. In general, the greater maximal numbers of bacteria were noted in coniferous than in deciduous timber. In coniferous logs, the maximal concentrations of bacteria in live tissue of sapwood were 


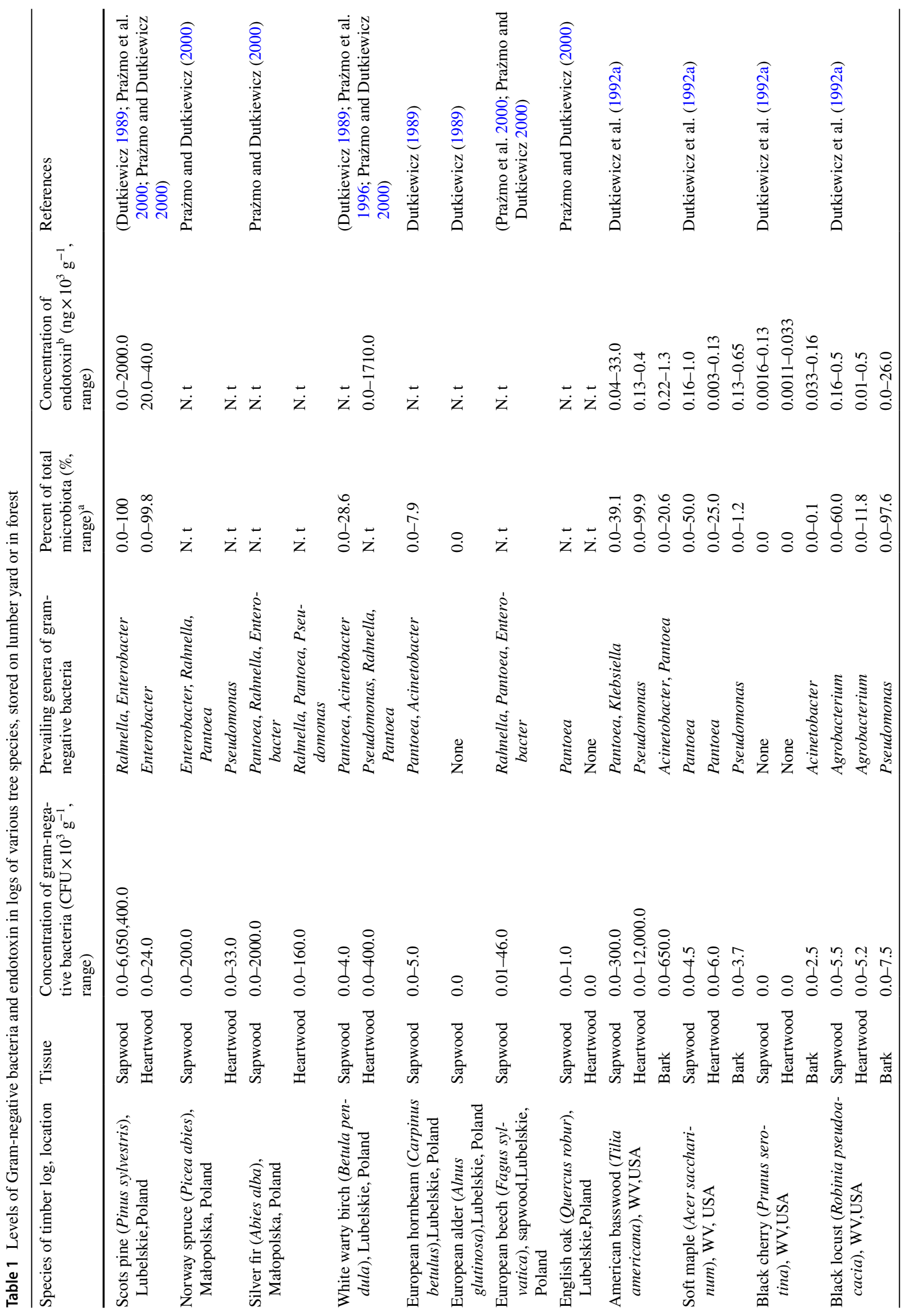




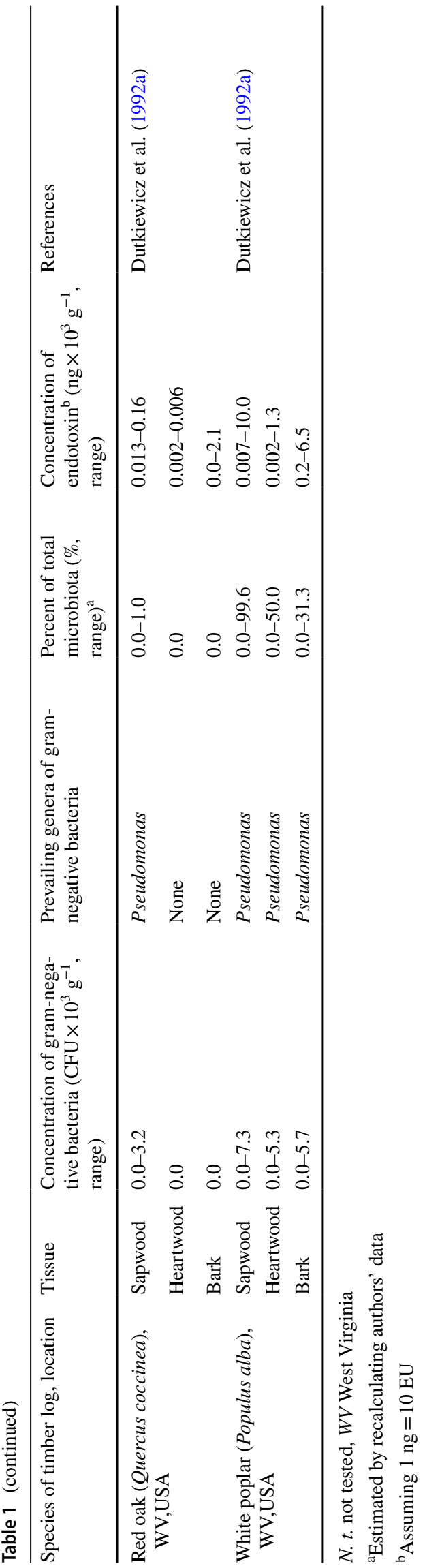

distinctly higher than in dead tissue of heartwood. By contrast, in deciduous logs, the concentrations of bacteria in the sapwood and heartwood were similar. The numbers in bark (determined only in the samples from USA) were generally similar to those found in the inner tissues. Among the strains isolated from coniferous and deciduous timber in Poland dominated those belonging to family Enterobacteriaceae (e.g., Pantoea spp., Rahnella spp., Enterobacter spp.), while among those isolated from deciduous timber in USA, the most prevalent were strains belonging to the family Pseudomonadaceae (Pseudomonas spp.). Gram-negative bacteria formed a marked proportion of the total microbiota (bacteria + fungi) isolated from timber, which varied within wide limits from 0.0 to $100 \%$ (Table 1).

A part of wood samples taken in Poland and all the samples taken in the USA were examined for the content of endotoxin, a macromolecular constituent of the cell wall of Gram-negative bacteria which may exert respiratory toxicity when inhaled (discussed in detail in the further part of this article). The tested samples contained the biologically active endotoxin in the wide range of $0.0-2000.0 \times 10^{3} \mathrm{ng} \mathrm{g}^{-1}$ (Table 1). In the samples taken in the USA, a highly significant correlation $(P<0.001)$ was found between the levels of Gram-negative bacteria and endotoxin (Dutkiewicz et al. 1992a). No significant differences could be found between the concentrations of endotoxin in bark versus inner wood tissues (sapwood and heartwood).

\section{Levels of gram-negative bacteria in the air of wood-processing facilities, commonest genera, levels of endotoxin}

Table 2 presents levels of Gram-negative bacteria occurring in the air of breathing zone of various wood-processing facilities contaminated with wood dust, located in Australia, Italy, Poland, and Switzerland. The numbers of bacteria ranged from 0.0 to $21.9 \mathrm{CFU} \times 10^{3} \mathrm{~m}^{-3}$; however, the interpretation of the data was hampered by the lack of widely accepted allowable values for the numbers of airborne microorganisms and their products. In 6 out of 13 cases, the maximal numbers exceeded a value of $1.0 \mathrm{CFU} \times 10^{3} \mathrm{~m}^{-3}$ which was proposed as allowable by Malmros et al. (1992) for premises polluted with organic dusts. Similarly as in timber, two groups of Gram-negatives strains may be distinguished among the strains isolated from the air contaminated with wood dust. The first, slightly more numerous, was formed by the bacteria classified within the Enterobacteriaceae family (e.g., Rahnella spp., Pantoea spp., Enterobacter spp., Klebsiella spp.) while the second consisted mostly of the members of Pseudomonadaceae family (e.g., Pseudomonas spp., Flavimonas spp., Burkholderia spp.).

In contrast to the potential allergenic role of Gramnegative bacteria that is largely underestimated, their role 
Table 2 Concentration of Gram-negative bacteria in the air of wood-processing facilities

\begin{tabular}{|c|c|c|c|c|c|}
\hline Country & Type of facility & $\begin{array}{l}\text { Concentration of Gram- } \\
\text { negative bacteria in the air } \\
\left(\mathrm{CFU} \times 10^{3} \mathrm{~m}^{-3}\right) \text { (range) }\end{array}$ & $\begin{array}{l}\text { Prevailing genera of gram- } \\
\text { negative bacteria }\end{array}$ & $\begin{array}{l}\text { Percent of total } \\
\text { microbiota }(\%)^{\mathrm{a}}\end{array}$ & References \\
\hline Finland & Paper mill & $1.3^{\mathrm{b}}$ & Klebsiella & N. e & Niemela et al. (1985) \\
\hline Poland & $\begin{array}{l}\text { Sawmill processing birch } \\
\text { (Betula pendula) } \operatorname{logs}\end{array}$ & $0.0-0.48$ & Pseudomonas & N. e & Prażmo et al. (1996) \\
\hline Australia & $\begin{array}{l}\text { Sawmills processing } \\
\text { eucalyptus }\end{array}$ & $3.3-14.1$ & N. $r$ & $8.1-44.5$ & Alwis et al. (1999) \\
\hline Australia & $\begin{array}{l}\text { Joineries (processing vari- } \\
\text { ous woods) }\end{array}$ & $0.4-15.1$ & N. $r$ & $7.7-41.8$ & Alwis et al. (1999) \\
\hline Poland & $\begin{array}{l}\text { Sawmill processing pine } \\
\text { (Pinus sylvestris) logs }\end{array}$ & $0.0-0.6$ & $\begin{array}{l}\text { Rahnella, Enterobacter, } \\
\text { Pantoea }\end{array}$ & N. e & Prażmo et al. (2000) \\
\hline Poland & $\begin{array}{l}\text { Sawmill processing beech } \\
\text { (Fagus sylvatica) } \operatorname{logs}\end{array}$ & $7.8-13.0$ & Rahnella & N. e & Prażmo et al. (2000) \\
\hline Poland & Sawmills & $0.04-21.9$ & Rahnella & $0.3-55.0$ & $\begin{array}{l}\text { Dutkiewicz et al. (2001a; } \\
\text { b, c) }\end{array}$ \\
\hline Poland & $\begin{array}{l}\text { Fiberboard and chipboard } \\
\text { factories }\end{array}$ & $0.3-5.7$ & $\begin{array}{l}\text { Acinetobacter, Pantoea, } \\
\text { Pseudomonas, Rahnella }\end{array}$ & $4.0-25.0$ & $\begin{array}{l}\text { Dutkiewicz et al. (2001a; } \\
\text { b, c) }\end{array}$ \\
\hline Poland & Furniture factories & $0.0-5.7$ & $\begin{array}{l}\text { Rahnella, Pseudomonas, } \\
\text { Acinetobacter }\end{array}$ & $0.0-20.6$ & $\begin{array}{l}\text { Krysińska-Traczyk et al. } \\
\text { (2002) }\end{array}$ \\
\hline Poland & Paper mills & $0.01-0.31$ & $\begin{array}{l}\text { Enterobacter, Pantoea, } \\
\text { Rahnella, Klebsiella }\end{array}$ & N. e & Prażmo et al. (2003) \\
\hline Switzerland & Sawmills & $0.0-0.8$ & $\begin{array}{l}\text { Burkholderia, Flavimonas, } \\
\text { Pseudomonas }\end{array}$ & $0.0-2.5$ & Oppliger et al. (2005) \\
\hline Italy & Sawmills and carpentries & $0.0-0.16$ & $\begin{array}{l}\text { Klebsiella, Pantoea, Enter- } \\
\text { obacter, Aeromonas }\end{array}$ & $0.0-5.5$ & Gioffré et al. (2012) \\
\hline Poland & Joineries & $\leq 0.08$ & Flavimonas & $\leq 1.0$ & Górny et al. (2017) \\
\hline Poland & Wood pellet production & 0.0 & None & 0.0 & Górny et al. (2019) \\
\hline
\end{tabular}

$N$. $e$ not estimated, $N$. $r$. not reported

aEstimated by recalculating authors' data

${ }^{\mathrm{b}}$ Upper limit of coliform bacteria

as producers of endotoxin causing febrile reaction among woodworkers has been appreciated by many authors engaged in the protection of the health of woodworkers. This was reflected by studies on the levels of airborne endotoxin in wood-processing facilities polluted with wood dust. Table 3 presents the results of the 21 studies performed in 12 countries. As seen, these levels ranged within wide limits between $10^{-2}$ and $10^{3} \mathrm{ng} / \mathrm{m}^{3}$. Maximal values exceeded the allowable exposure level $\left(9 \mathrm{ng} / \mathrm{m}^{3} \sim 90 \mathrm{EU} / \mathrm{m}^{3}\right.$ proposed by the Health Council of the Netherlands, 2010) in 13 out of 21 cases.

\section{Gram-negative bacteria as a potential cause of respiratory disease in woodworkers}

\section{Allergy}

A massive occupational exposure to particulate or liquid bioaerosols may result in hypersensitivity pneumonitis (HP). This is usually an occupational disease of the peripheral lung tissue, which in advanced stage may lead to interstitial fibrosis. The disease is caused by the interaction of immunocompetent cells, classified as Th1 allergic response, with the large quantities of microbial or animal allergens associated with organic dusts. The pathogenic reaction leads to lymphocytic and often granulomatous inflammation of the lower parts of lungs and finally to fibrosis (Selman et al. 2012; Quirce et al. 2016; Sforza and Marinou 2017; Nogueira et al. 2019; Greenberger 2019).

Since 1932, at least 22 papers were published in which HP cases caused by the occupational exposure to the inhalation of wood dust were described. Of these, in 17 filamentous fungi (belonging to Alternaria, Aspergillus, Aureobasidium, Cryptostroma, Graphium, Mucor, Paecilomyces, Penicillium, Pullularia, Rhizopus, and Trichoderma genera) were determined as a cause of disease, in two thermophilic bacteria (Thermoactinomyces vulgaris, Saccharomonospora viridis), in one endospore-forming bacillus (Bacillus subtilis), and in one wood (Cabreuva) itself (Towey et al. 1932; Minárik et al. 1983; NIOSH 
Table 3 Concentration of bacterial endotoxin in the air of wood-processing facilities

\begin{tabular}{|c|c|c|c|}
\hline Country & Type of facility & $\begin{array}{l}\text { Concentration of endotoxin (ng } \\
\mathrm{m}^{-3} \text { ) (average values) }\end{array}$ & References \\
\hline Sweden & Furniture factories & $1.2-350.0$ & Wilhelmsson et al. (1984) \\
\hline Poland & Sawmill & 75.0 & Prażmo et al. (1996) \\
\hline Australia & Sawmills & $1.3-21.1$ & Alwis et al. (1999) \\
\hline Australia & Joineries & $0.7-9.8$ & Alwis et al. (1999) \\
\hline Sweden & Paper mill (bark cleaning) & $23.0-220.0$ & Rylander et al. (1999) \\
\hline Canada (British Columbia) & Sawmills & $1.0-3.6$ & Dennekamp et al. (1999) \\
\hline Canada (Quebec) & Sawmills & $32.3-594.4^{\mathrm{a}}$ & Duchaine et al. (2000) \\
\hline New Zealand & Sawmills & $2.8-29.5^{\mathrm{a}}$ & Douwes et al. (2000) \\
\hline Poland & Sawmills & $240.0-4000.0$ & Dutkiewicz et al. (2001a) \\
\hline Poland & Fiberboard and chipboard factories & $0.0125-197.4^{\mathrm{a}}$ & Dutkiewicz et al. (2001c) \\
\hline New Zealand & Plywood mill & $1.2-7.6^{\mathrm{a}}$ & Fransman et al. (2003) \\
\hline Poland & Paper mill & $20.0-207.7$ & Prażmo et al. (2003) \\
\hline Tanzania & Joineries & $4.0-38.4^{\mathrm{a}}$ & Rongo et al. (2004) \\
\hline Switzerland & Sawmills & $0.04-1.8^{\mathrm{a}}$ & Oppliger et al. (2005) \\
\hline USA & Joineries & 1.1 & Harper and Andrew (2006) \\
\hline Croatia & Sawmills & $26.2-28.1^{\mathrm{a}}$ & Pipinić et al. (2010) \\
\hline Italy & Sawmills and carpentries & $0.14-6.93$ & Gioffré et al. (2012) \\
\hline Poland & Joineries & 2.51 & Górny et al. (2017) \\
\hline Poland & Wood pellet production & $4.1-214.7$ & Górny et al. (2019) \\
\hline Ethiopia & Particleboard factories & $6.2^{\mathrm{a}}$ & Asgedom et al. (2020) \\
\hline Norway & Sawmills & $1.2^{\mathrm{a}}$ & Straumfors et al. (2020) \\
\hline
\end{tabular}

${ }^{\mathrm{a}}$ Value(s) converted from Endotoxin Units (EU) assuming $10 \mathrm{EU}=1 \mathrm{ng}$

1987; Eduard et al. 1994; Selman et al. 2012; Færden et al. 2014; Nogueira et al. 2019).

To the best of our knowledge, none Gram-negative bacterium was described until recently as a cause of HP in woodworkers or any other individuals exposed to wood dust. In our recent study (Mackiewicz et al. 2019), a Gram-negative bacterium $P$. agglomerans was identified as a main causative agent of acute HP in 5 workers employed as sawyers in the furniture factory ( 3 females and 2 males, aged $40-53$ years), exposed to the inhalation of dust from white warty birch (Betula pendula) for 1-4 years. It is noteworthy that all the patients were exposed before to the dust from Scots pine (Pinus sylvestris) and had not any adverse symptoms until changing production from pine to birch.

All patients reported work-related symptoms associated with exposure to birch dust. Chest X-ray revealed interstitial diffuse changes mostly in lower and middle lung fields, while in high-resolution computed tomography (HRCT), ground-glass attenuations were observed. Bronchoalveolar lavage (BAL) demonstrated a typical lymphocytic alveolitis. According to the clinical observation and diagnostic tests, four patients were diagnosed with acute HP and one with subacute HP (Mackiewicz et al. 2019).

Microbiological examination of the birch wood samples associated with eliciting respiratory and general symptoms in patients, performed with the use of above-mentioned drilling device (Dutkiewicz et al. 1989), revealed an extremely large, site-depending diversity in the concentration and species composition of the microbiome. The concentration of microorganisms colonizing a brownish ring in the central part of the wooden blocks, corresponding to heartwood and denoted as "A," was about 10,000 times lower compared to those colonizing the peripheral, yellowish ring corresponding to sapwood and denoted as "B" $\left(4.8 \times 10^{4} \mathrm{CFU} \mathrm{g}^{-1}\right.$ vs. $4.2 \times 10^{8} \mathrm{CFU} \mathrm{g}^{-1}$ ) (Fig. 1). A high prevalence of microorganisms in the peripheral ring " $\mathrm{B}$," presumably consisted of live tissue, could be explained by a better supplementation with nutrients compared to the central ring " $\mathrm{A}$ " consisted of dead tissue. The most common organisms colonizing ring " $B$ " were Gram-negative bacteria identified as belonging to the species Pantoea agglomerans (38.7\% of the total count) and Aeromonas spp. (16.6\%) and Gram-positive, coryneform actinobacterium, initially determined as Microbacterium barkeri (43.7\%).

Taking into account the increasing significance of molecular identification compared to that obtained by culture, we compared in this work quantitative versions of both methods with relation to Pantoea agglomerans. The results, which have not been published as yet, are included as an "Online ESM" to this article. 


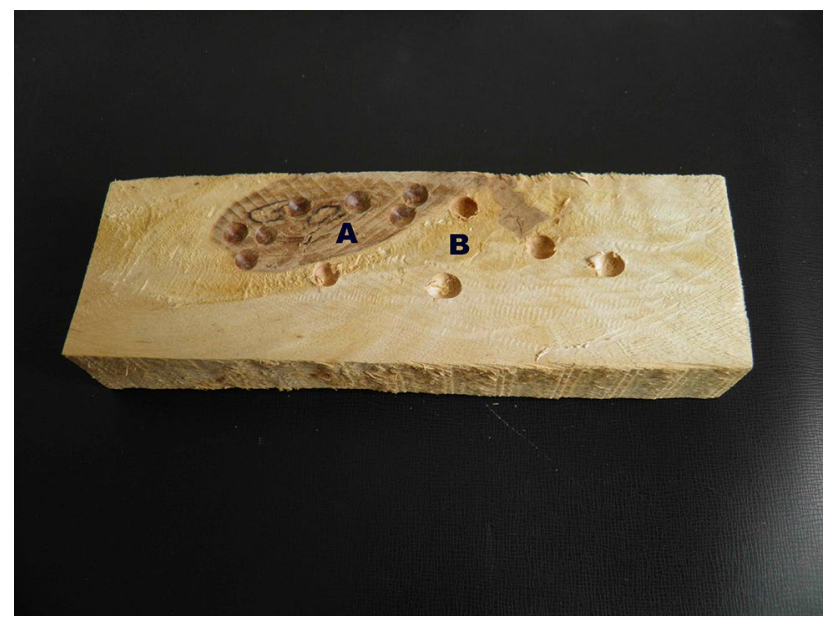

Fig. 1 Cylindrical block cut from the transverse section of birch (Betula pendula) log. A central, brownish ring; B peripheral, yellowish ring. Hollows in the wood indicate sites of sampling with the drilling device (according to Mackiewicz et al. 2019)

Considering the fact that immunopathologic reaction in $\mathrm{HP}$ is initiated by an exposure to large amounts of adverse factors, usually microorganisms, and therefore, the organisms prevailing in the material associated with evoking symptoms are almost surely the disease-causing agents (Towey et al. 1932; Pepys et al. 1963; Eduard et al. 1994; Milanowski et al. 1998; Selman et al. 2012; Nogueira et al. 2019); Pantoea agglomerans and Microbacterium barkeri were selected as antigens for allergological tests aiming to identify causative agent(s) of the disease observed in the patients. All the patients were examined with the inhalation challenge as a basic test and with the test for inhibition of leukocyte migration (MIF) and agar-gel precipitation test as auxiliary ones. In all tests, lyophilized saline extracts of bacterial mass were used in the doses adjusted to the test (Milanowski et al. 1998; Mackiewicz et al. 2019).

The inhalation challenge had been used with very low concentrations of bacterial antigens $\left(20 \mu \mathrm{g} \mathrm{ml}^{-1}\right)$ enabling the detection of specific allergy but excluding a possibility of adverse side effects and/or nonspecific reactions caused by endotoxin. The total amount of allergen absorbed by one patient during the test was estimated as $2.16 \mu \mathrm{g}$. All five patients responded positively to the challenge with $P$. agglomerans antigen, as assessed by spirometry (drop of the forced vital capacity (FVC) below $10 \%$ of the initial value, significant $(P<0.01)$ decrease of $\mathrm{FVC}$ and $\mathrm{FEV}_{1}$ values, as assessed by $\chi^{2}$ test) auscultation and symptomatology. The strongest decrease of spirometric values was expressed after $8 \mathrm{~h}$ post-challenge (Fig. 2). Two out of five examined patients responded positively to the challenge with M. barkeri antigen.

Significant inhibition of leukocyte migration in the presence of the Pantoea agglomerans antigen was found in 4 out 5 tested workers. The results indicate that this antigen had a potential to initiate the immunopathologic cellular reaction that is most significant in the pathogenesis of HP. Only in one serum out of five tested workers sera, the presence of precipitin antibodies directed against $P$. agglomerans antigen was revealed suggesting that the time of workers' exposure was not long enough to produce precipitins that are known markers of long-lasting exposure to adverse antigens, but not necessarily of disease (Pereira et al. 2016; Nogueira et al. 2019). Two out of five patients were positive in the MIF test with M. barkeri and none in the precipitin test with this antigen.

In conclusion, Pantoea agglomerans was recognized as a primary agent causing HP in the workers exposed to dust from birch wood, and Microbacterium barkeri as a secondary agent, probably potentiating the effects of sensitization
Fig. 2 Results of inhalation challenge with the extract of Pantoea agglomerans in patient No. 4 compared to the response after exposure to $\mathrm{NaCl}$. Note distinct drops of FVC and $\mathrm{FEV}_{1}$ values $8 \mathrm{~h}$ post exposure to P. agglomerans (unpublished graph)

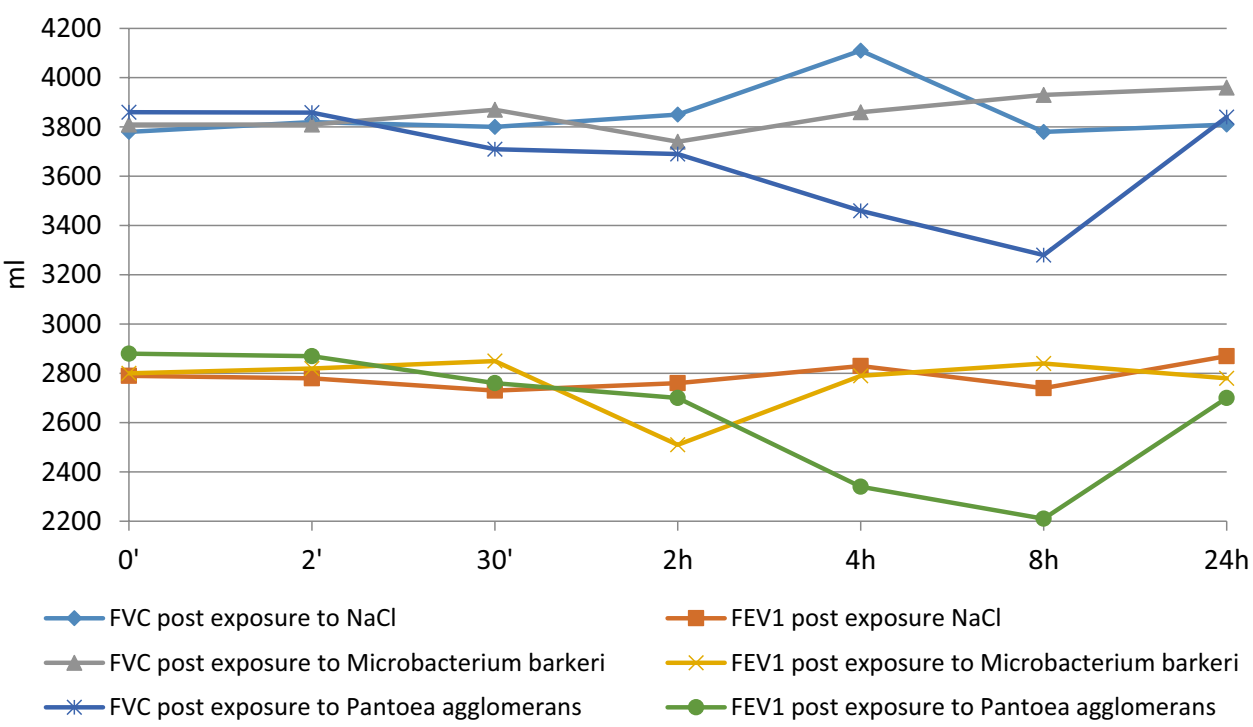


to Gram-negative bacterium. As preceding microbiological examination of birch wood has not demonstrated large quantities of Gram-negative bacteria (Table 1), the extremely high level of these bacteria found in this work was presumably not associated with the tree species but rather with not yet recognized nutritional and/or microclimatic conditions allowing their expansion in wood tissue. This view can be further supported by an observation that the patients worked for a long time safely with pine wood, which could contain large quantities of Gram-negative bacteria and endotoxin as demonstrated by our earlier studies (Table 1). Therefore, the respiratory hazard should be considered as a combination of nutritional and microclimatic factors that may cause development of the potentially pathogenic bacteria in any kind of timber.

Pantoea agglomerans (synonyms: Enterobacter agglomerans, Erwinia herbicola), member of the Enterobacteriaceae family, recently proposed to be included into Erwiniaceae, is probably one of the most common microorganisms living on Earth. Originally plant inhabitant, developing immensely as epi- or endophytic organism in multitude of plant species, it was found also in animal and human tissues, soil, water, and sewage (Dutkiewicz et al. 2015). $P$. agglomerans has been isolated from grain and grain dust in USA and Poland, in the concentrations ranging from $10^{5}$ to $10^{7} \mathrm{CFU} \mathrm{g}^{-1}$ (DeLucca et al. 1984; Milanowski et al. 1998; Dutkiewicz et al. 2016a). It has been identified as a common cause of HP in the Polish agricultural workers exposed to the inhalation of organic dusts, mostly from grain (Kuś , 1980a; b; Milanowski et al. 1998), less often from flour (Kuś , 1980a; b), clover (Milanowski et al. 1998), and herbs (Mackiewicz et al. 1999). The bacterium caused also a HP case described in a German farmer (Sennekamp et al. 2012).

The results of the above presented paper by Mackiewicz et al. (2019) clearly demonstrate that $P$. agglomerans could be also an important cause of HP among workers of wood industry.

Little is known about the role of other Gram-negative bacteria present in wood dust as potential causative agents of respiratory disease in exposed individuals. Out of bacteria belonging to Enterobacteriaceae family, the primary candidates are genera Rahnella and Enterobacter. It has been demonstrated by the intradermal skin test that the workers of the sawmill processing coniferous wood (pine), exposed during their work to the inhalation of large quantities of Rahnella spp. particles, revealed a high rate $(65 \%)$ of the early allergic grade 2 reactions of the diameter $\geq 10 \mathrm{~mm}$ to the extract of this bacterium, compared to less exposed workers of the sawmill processing deciduous wood (oak and birch) who reacted with the rate of $28.9 \%$, and to members of not exposed reference group who reacted with the rate of $18.7 \%$. These differences proved to be highly significant $(P<0.001)$ (Dutkiewicz et al. 2001b). Unexpectedly, also less exposed workers of furniture factory showed a high rate of positive skin grade 2 reactions, significantly greater compared to the reference group $(64.6 \%$ vs. $18.7 \%, P<0.001)$ (Skórska et al. 2002). Nevertheless, it must be stressed that these data provided only information on immunological, but not clinical sensitization and so far proved only an allergenic potential of Rahnella, but not ability to cause bronchial asthma or any other disease.

The allergenic potential may reveal also bacteria of family Pseudomonadaceae, especially Pseudomonas spp. commonly detected in wood tissue (Table 1) and in air contaminated with wood dust (Table 2). Bernstein et al. (1995) demonstrated that bacteria belonging to this genus may cause HP in the workers exposed to contaminated metalworking fluid aerosols. The furniture factory workers showed a high incidence of precipitin reactions to Pseudomonas maltophilia, significantly greater than in reference group (27.1\% vs. 0.0\%, $P<0.01)$ (Skórska et al. 2002). Although this was only an immunological reactiveness, it should be considered as an important indication for further studies on Pseudomonas spp. as a potential cause of allergic diseases resulting from the exposure to wood dust.

\section{Endotoxin effects}

When inhaled during work together with wood dust or other organic dusts, Gram-negative bacteria may affect human health mainly by two pathogenic reactions resulting in lung inflammation. Of which, the first is T-cell-dependent specific allergic reaction leading to hypersensitivity pneumonitis (HP) with radiographic changes, manifested in chronic stage of disease as fibrosis, whereas the second is an unspecific fever reaction without radiographic changes caused by endotoxin, a high-molecular compound produced by Gramnegative bacteria. The type of the reaction depends on both the individual's characteristics (age, genetic determinants, immunological profile etc.) and circumstances of exposure. Out of Gram-negative bacteria associated with wood dust a special attention should be paid in this respect to the ubiquitous species Pantoea agglomerans, recently indicated as an agent causing exacerbations of the chronic obstructive pulmonary disease (COPD) (Shrestha et al. 2021). Earlier, it has been demonstrated experimentally that this species produces as well a potent endotoxin (Dutkiewicz 1976; Rylander and Lundholm 1978).

Endotoxin is a biologically active lipopolysaccharide (LPS) that is an integral component of the outer membrane of the cell wall of Gram-negative bacteria. This is a macromolecular polymer, consisting of hydrophobic (lipidic) and hydrophilic (polysaccharide) moieties. The biological properties of LPS strongly depend on chemical composition and structure. The molecule contains three structural 
parts: lipid A, core oligosaccharide, and O-specific polysaccharide. Lipid A is responsible for nonspecific pathophysiological responses, including fever, intravascular coagulation, hypotension, or shock. To date, the lipid A part of $P$. agglomerans LPS has conveyed the special attention since it has been shown to contain at least two types of lipid A of different acylation levels (Tsukioka et al. 1997): the hexaacyl lipid A that shows a high biological activity, including endogenous tumor necrosis factor alpha (TNF $\alpha$ ) induction, while the activity of the heptaacyl lipid A is slightly lower (Zdorovenko et al. 2017). Specific features of the LPS, the number of fatty acids in lipid A, as well as their distribution, chain length, and stereochemistry, are significant for many activities, including toxicity and pyrogenicity (Zdorovenko et al. 2017, 2018, 2019). To date, biological activity of endotoxins was found to be stronger in the dust-borne Enterobacteriaceae species (Pantoea agglomerans, Rahnella spp.) than in non-Enterobacteriaceae ones (Acinetobacter calcoaceticus, Alcaligenes faecalis) (Dutkiewicz et al. 1988). Thus, besides P. agglomerans, also the strains of Rahnella, Enterobacter and Klebsiella commonly occurring in wood dust (Prażmo et al. 2000; Gioffré et al. 2012) are regarded as producers of a potent, active endotoxin.

Fragmentation of the LPS-containing cell wall, usually following desiccation or fission, easily releases endotoxincontaining particles into dust in the form of microvesicles surrounded by a lipid bilayer and measuring mostly $10-60 \mathrm{~nm}$. These nanoparticles, structurally macromolecular heteropolymers of LPS with proteins and phospholipids of the cell wall, are known in the literature under various names, such as outer membrane vesicles-OMVs (Chudzik and Paściak 2020), extracellular vesicles-EVs (Kim et al. 2013), or ultrafine particles-UFP (Yang et al. 2020). For the first time, environmental release of such nanoparticles has been demonstrated in the sapwood tissue of American basswood (Tilia americana) colonized by Pantoea agglomerans (Dutkiewicz et al. 1992b). They were released by peeling off the outer membrane of bacterium and enlarged after detachment (Fig. 3). The identity of these microvesicles with parent organism was confirmed by immunostaining with the rabbit antiserum against LPS of $P$. agglomerans followed by labeling with immunogold conjugated with anti-rabbit IgG (Fig. 4). Similarly to biological activity, the ability to release endotoxin particles in the form of microvesicles is strongest among Enterobacteriaceae strains. Nevertheless, it has been observed also in other Gram-negative bacteria, for example in Pseudomonas species colonizing pathologically changed heartwood tissue of birch (Betula pendula) described as "wetwood" (Fig. 5) (Prażmo et al. 1996).

Endotoxin-containing microvesicles (ECMVs) are easily inhaled by humans together with dust because of small dimensions and aerodynamic shape. Afterwards, they cause a nonspecific activation of lung macrophages, which release

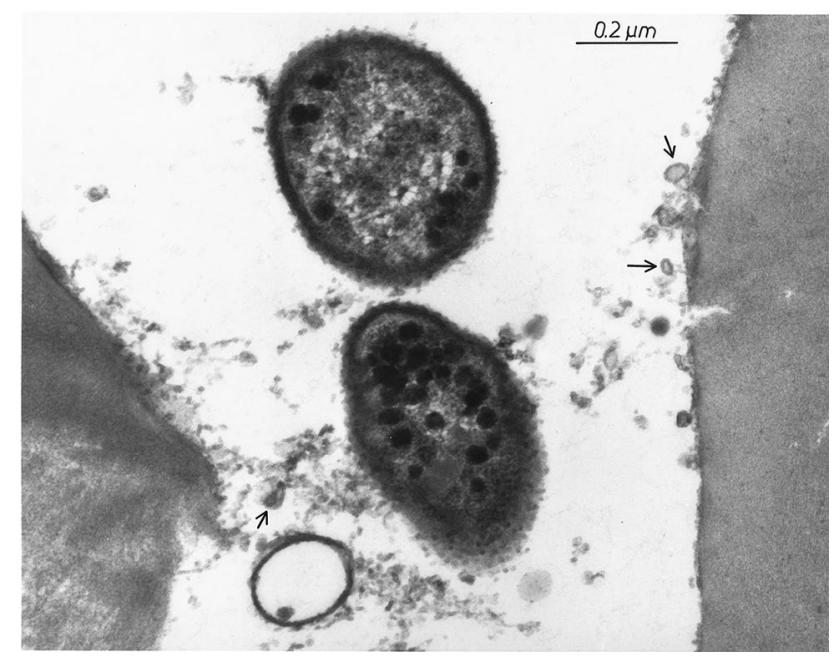

Fig. 3 Thin-sectioned sample of pulverized wood from American basswood stained with uranyl acetate and lead citrate, showing two cells of Gram-negative bacteria (presumably Pantoea agglomerans) and numerous membrane vesicles (some marked with arrows) in the lumen of a wood cell, TEM (according to Dutkiewicz et al. 1992b)

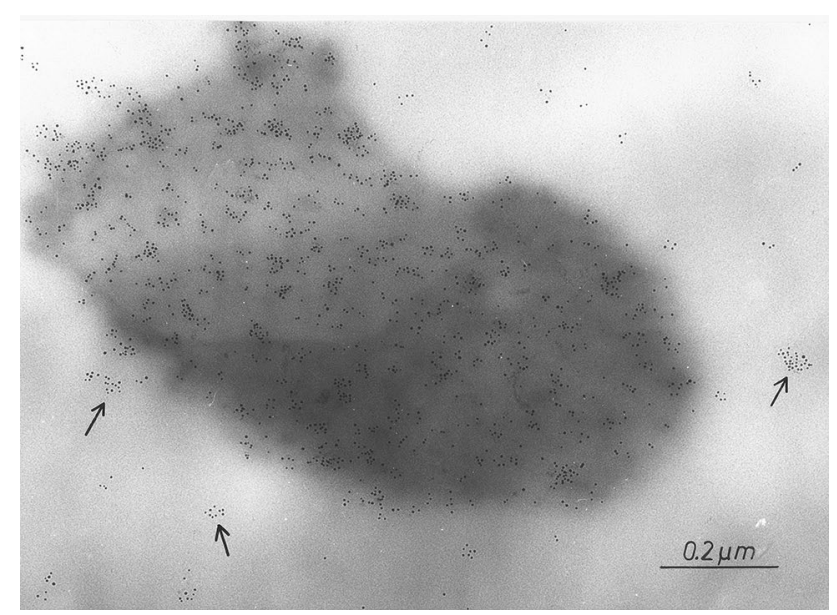

Fig. 4 Thin-sectioned sample of pulverized wood from American basswood immunostained with the rabbit antiserum against LPS of $P$. agglomerans and gold-labeled with anti-rabbit IgG. Structure corresponding to the cell of $P$. agglomerans is seen, stained positively with immunogold. Arrows outside the cell show aggregations of gold particles to smaller structures corresponding in shape and size to membrane vesicles, TEM (according to Dutkiewicz et al. 1992b)

numerous substances known as inflammatory mediators. Symptoms include an inflammatory lung reaction, chest tightness, fever, gas exchange disorders, and bronchospasm, without radiographic changes (Dutkiewicz et al. 2016a). Immunotoxic disorders caused by the endotoxin inhalation occur mostly in young people and are known under the names "organic dust toxic syndrome" (ODTS) or "toxic pneumonitis." In earlier studies, cases of this disease most 


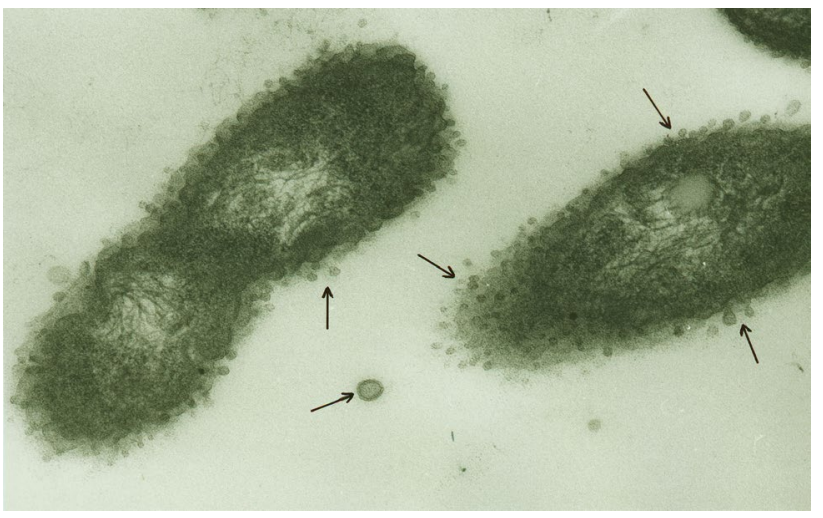

Fig. 5 Thin-sectioned sample of pulverized wetwood from white warty birch stained with uranyl acetate and lead citrate, showing two cells of Gram-negative bacteria (presumably Pseudomonas spp.) and numerous membrane vesicles (some marked with arrows) peeling from the outer membranes of these bacteria, TEM (according to Prażmo et al. 1996)

probably caused by $P$. agglomerans endotoxin present in grain or cotton were described, respectively, as "grain fever" (Dutkiewicz et al. 2016a) or "Monday fever" (byssinosis) (Rylander 1981).

Strong immunostimulating properties of ECMVs fraction separated from Rahnella sp. or Pantoea agglomerans cells by differential sucrose gradients was demonstrated by long-term inhalation experiments in rabbits (Skórska et al. 1996; Dutkiewicz et al. 2005). The experiments showed that microvesicular fraction of endotoxin, corresponding to native form of this compound naturally occurring in the air polluted with wood dust and inhaled by exposed workers, caused a large and highly significant increase in the concentration of the circulating proinflammatory cytokines: total interferon (IFN), interleukin- $1 \alpha$ (IL-1 $\alpha$ ), and tumor necrosis factor $\alpha(\mathrm{TNF} \alpha)$. Besides the nonspecific proinflammatory activity, ECMVs fraction elicited also specific cellular and humoral response in exposed rabbits, thus, strengthening the adverse immune stimulation. The results of this experiment suggest that in real life could be only a thin line between the specific allergic reaction(s) causing HP and nonspecific endotoxin reaction(s) causing ODTS, which may even potentiate each other. The airborne, microvesicular endotoxin produced by Gram-negative bacteria probably elicits toxic pneumonitis by itself or may augment the allergenic effects of these bacteria and exacerbate the clinical course of HP.

Immunostimulative properties of dust-borne bacterial microvesicles have been confirmed by Kim et al. (2013) who demonstrated on mouse model that repeated intranasal application of ECMVs fraction separated from mattress dust is able to induce proinflammatory cytokines and neutrophilic pulmonary inflammation. More recently, Yang et al. (2020) raised an interesting hypothesis that the inhalation exposure to low levels of LPS-containing microvesicles may cause Th2-mediated eosinophilic asthma, whereas the exposure to high levels may cause Th17-mediated chronic pulmonary diseases such as neutrophilic asthma, COPD, and lung cancer. Accordingly, these authors regard microvesicles produced by Gram-negative bacteria as a key etiological agent of the chronic pulmonary inflammatory diseases. In the recent review on bacterial extracellular vesicles, Chudzik and Paściak (2020) present a wide range of their vital functions including pathogenic modulation of host's immune system, mediation in the communication between bacterial cells with the use of signal molecules, horizontal gene transfer, protection of parent cell(s), enzyme-based acquisition of nutrients, and ability of the biofilm formation.

So far, the occupational allergic diseases caused by the inhalation of wood dust were related mainly to filamentous fungi, actinobacteria, and wood constituents; hence, the Gramnegative bacteria in this role are "new players." In contrast, the importance of bacterial endotoxin as a possible cause of ODTS among woodworkers, along with substances produced by filamentous fungi, such as macromolecular $(1 \rightarrow 3)-\beta$-Dglucan or low-molecular volatile organic compounds (VOCs) is widely considered, which is reflected by the numerous studies worldwide presenting levels of airborne endotoxin in wood-processing facilities (see Table 3). This is an important assessment and indicator of occupational health risk and/or overall work hygiene in examined facilities.

The potential hazard of exposure to endotoxin was demonstrated by Rylander et al. (1999) in Sweden and in Australia by Mandryk et al. (2000) who reported a significant relationship between the levels of endotoxin in airborne wood dust and occurrence of work-related respiratory symptoms in exposed workers. Górny et al. (2019) found a significant correlation between the levels of endotoxin in the air of wood pellet production facilities in Poland, and levels of cytokines known as proinflammatory mediators in the nasal lavage from exposed workers.

To date, descriptions of the individual ODTS cases caused by the inhalation exposure to endotoxin in wood dust are rare. Most probably, one of them is that reported by Weber et al. (1993). These authors described the case of 52 year old male who developed fever, myalgia, and marked dyspnea $12 \mathrm{~h}$ after shoveling composted wood chips and leaves. Numerous fungal spores and large endotoxin concentrations ranging from 63.6 to $1.630 .0 \mathrm{ng} / \mathrm{m}^{3}$ were found in respirable dust samples indicating these factors as probable causative agents of the disease.

\section{Infection}

Little is known about work-related infections caused by Gram-negative bacteria in woodworkers. The risk of pulmonary infection could be associated with the presence of 
the species Klebsiella pneumoniae that has been isolated from wood tissue (Bagley et al. 1978), paper mill effluents (Caplenas et al. 1981), as well as from the air of paper mill and nasal cavities of exposed workers (Niemelä et al. 1985). More recently, this species has been identified, together with Klebsiella rhinoscleromatis, by Neghab et al. (2018) as one of the predominant Gram-negative bacteria in the air of sawmills in Iran. All these data are in accordance with the opinion expressed by Munoz et al. (2006) that wood-based bedding is a main source of Klebsiella pneumoniae on dairy farms. Nevertheless, to the best of our knowledge, none case of pneumonia caused by this bacterium was described in a person exposed to wood dust.

Out of other timber-colonizing Gram-negative bacteria, Pantoea agglomerans and Rahnella aquatilis were identified as causative agents of opportunistic infections in humans. The infections occur mostly in immunocompromised persons and are often hospital acquired (Chang et al. 1999; Dutkiewicz et al. 2016b). Moreover, P. agglomerans causes wound infections, following piercing or laceration of skin with plant material, such as thorn or wooden splinter. The latter pathway should be considered as a possible pathogen transmission to woodworkers (Dutkiewicz et al. 2016b).

\section{Epidemiology and clinical diagnosis}

Compared to filamentous fungi, the role of Gram-negative bacteria in causing occupational disease in woodworkers is less known, and at present, there are no reliable epidemiological data on this subject. Recently, organic dust toxic syndrome (ODTS, toxic pneumonitis) is probably the most common disorder caused by Gram-negative bacteria and endotoxin present in the airborne wood dust. A significant correlation between the levels of endotoxin and/or Gram-negative bacteria in airborne wood dust and occurrence of work-related symptoms corresponding to ODTS were reported for the populations of workers employed in the Swedish paper mills at debarking the logs (Rylander et al. 1999), as well as for those working in the 'green sawmills' (processing fresh logs, mainly eucalypts) in Australia (Mandryk et al. 2000) and in the Iranian sawmills (Neghab et al. 2018). The incidence of ODTS in woodworkers is most probably distinctly higher compared to hypersensitivity pneumonitis (HP). Based on the epidemiological data reported by Malmberg et al. (1988) for Swedish farmers, we may presume for a population of woodworkers a yearly incidence of HP circa 2-3/10,000 workers and for ODTS circa $1 / 100$ workers, i.e., 30-50 times higher. Most probably, these figures tend to decrease along with the technical improvement of ventilation systems in wood-processing facilities.

Flu-like symptoms (dyspnea, cough, fever, shivering) which are characteristic for ODTS, are similar to those appearing in the acute stage of HP. The correct diagnosis of the latter is based on the presence of radiographic changes and specific immune reactions with bacterial antigens, which are usually absent in ODTS. Also, the ODTS symptoms may occur after single massive exposure, whereas those of acute HP appear after repeated exposures needed for the formation of specific immunity (Malmberg et al. 1988).

So far, there are only few information on infectious diseases caused by timber-colonizing Gram-negative bacteria. Despite the presence of potentially infectious species (Klebsiella pneumoniae, Klebsiella rhinoscleromatis, Pantoea agglomerans) in wood and wood dust, the probability of disease in immunocompetent workers is rather low. Such possibility could be considered in the case immunocompromised persons exposed to wood dust containing the abovementioned pathogens. Diagnosis should be based on the isolation of pathogen from body fluids and identification with biochemical, molecular, and immunological methods.

\section{Conclusions}

1. Gram-negative bacteria occur commonly in the inner tissues of stored coniferous and deciduous timber, showing a marked variation in the numbers. The greatest maximal numbers could be found in the live tissue of sapwood of coniferous timber. The common constituents of the Gram-negative biota are potentially pathogenic species of Enterobacteriaceae family of the genera Rahnella, Pantoea, Enterobacter, and Klebsiella.

2. The air of the wood-processing facilities is polluted with the wood-borne Gram-negative bacteria and their endotoxin (lipopolysaccharide, LPS), as demonstrated by numerous studies.

3. There are three potential pathways of the pathogenic impact of wood-borne Gram-negative bacteria on exposed woodworkers: allergic, immunotoxic, and infectious. Allergic impact of Gram-negative bacteria has been underestimated for a long time and might contributed to a long delay in the diagnosis of the first case of hypersensitivity pneumonitis (HP) caused by these bacteria. Hopefully, the recent demonstration of the first documented case of HP in woodworkers caused by Pantoea agglomerans developing extremely large quantities in birch sapwood would speed up finding of new wood-related cases of HP caused by this species and other Gram-negative bacteria, based on state-of-the-art clinical, immunological, and microbiological methods.

4. The second pathway of the pathogenic impact of wood-borne Gram-negative bacteria is associated with endotoxin, exerting strong immunotoxic (excessively immunostimulative) action. It has been demonstrated that endotoxin is released into wood dust in the form 
of microvesicles measuring mostly $10-60 \mathrm{~nm}$, by peeling off the outer membrane of bacterium. Endotoxincontaining microvesicles are easily inhaled by humans together with dust because of small dimensions and aerodynamic shape. Afterwards, they cause a nonspecific activation of lung macrophages, which release inflammatory mediators causing an inflammatory lung reaction, chest tightness, fever, gas exchange disorders, and bronchospasm, without radiographic changes. The resulting disease is known as "organic dust toxic syndrome" (ODTS) or "toxic pneumonitis."

5. The potential third pathway of the pathogenic impact is infection. The suspected species is Klebsiella pneumoniae that may occur in wood dust; however, this pathway has not been confirmed.

6. Summarizing, Gram-negative bacteria-inhabiting wood should be considered, together with filamentous fungi and actinobacteria, as important risk factors of occupational disease in woodworkers that could be either HP with allergenic background or toxic pneumonitis elicited by endotoxin.

Supplementary Information The online version contains supplementary material available at https://doi.org/10.1007/s00420-021-01829-1.

Funding The study was supported by Institute of Rural Health within a subsidy from the Ministry of Science and Higher Education in Warsaw, Poland.

Data availability The Pantoea agglomerans strain isolated from the birch wood was deposited at the Polish Collection of Microorganisms in the Institute of Immunology and Experimental Therapy of the Polish Academy of Science in Wrocław (Poland) under the number PCM 3041. The sequence of the 16S rRNA gene fragment determined in this study was deposited in the GenBank under accession number MW647906.1 (Pantoea agglomerans strain PCM3041 16S ribosomal RNA gene, partial sequence).

\section{Declarations}

Conflict of interest The authors declare they have no financial or nonfinancial interests.

Informed consent Informed consent was obtained from all individual participants included in the study.

Open Access This article is licensed under a Creative Commons Attribution 4.0 International License, which permits use, sharing, adaptation, distribution and reproduction in any medium or format, as long as you give appropriate credit to the original author(s) and the source, provide a link to the Creative Commons licence, and indicate if changes were made. The images or other third party material in this article are included in the article's Creative Commons licence, unless indicated otherwise in a credit line to the material. If material is not included in the article's Creative Commons licence and your intended use is not permitted by statutory regulation or exceeds the permitted use, you will need to obtain permission directly from the copyright holder. To view a copy of this licence, visit http://creativecommons.org/licenses/by/4.0/.

\section{References}

Alwis KU, Mandryk J, Hocking AD (1999) Exposure to biohazards in wood dust: bacteria, fungi, endotoxins $(1 \rightarrow 3)-\beta$-D-glucans. Appl Occup Environ Hyg 14(9):598-608. https://doi.org/10.1080/ 104732299302404

Asgedom AA, Bråtveit M, Schlünssen V, Moen BE (2020) Exposure to inhalable dust, endotoxin, and formaldehyde in factories processing particleboards from eucalyptus trees in Ethiopia. Environ Occup Health Pract. https://doi.org/10.1539/eohp. 2019-0016-OA

Bagley ST, Seidler RJ, Talbot HW Jr, Morrow JE (1978) Isolation of Klebsielleae from within living wood. Appl Environ Microbiol 36(1):178-185. https://doi.org/10.1128/aem.36.1.178-185.1978

Bernstein D, Lummus ZL, Santilli G, Siskosky J, Bernstein IL (1995) Machine operator's lung. A hypersensitivity pneumonitis disorder associated with exposure to metalworking fluid aerosols. Chest 108(3):636-641. https://doi.org/10.1378/chest.108.3.636

Caplenas NR, Kanarek MS, Dufour AP (1981) Source and extent of Klebsiella pneumoniae in the paper industry. Appl Environ Microbiol 42(5):779-785. https://doi.org/10.1128/aem.42.5. 779-785.1981

Chan-Yeung M (1994) Mechanism of occupational asthma due to Western red cedar (Thuja plicata). Am J Ind Med 25(1):13-18. https://doi.org/10.1002/ajim.4700250106

Chang CL, Jeong J, Shin JH, Lee EY, Son HC (1999) Rahnella aquatilis sepsis in an immunocompetent adult. J Clin Microbiol 37(12):4161-4162. https://doi.org/10.1128/JCM.37.12. 4161-4162.1999

Chudzik A, Paściak M (2020) Bacterial extracellular vesicles as cell-cell communication mediators. Postepy Hig Med Dosw 74:572-588

DeLucca AJ II, Godshall MA, Palmgren MS (1984) Gram-negative bacterial endotoxins in grain elevator dusts. Am Ind Hyg Assoc J 45(5):336-339. https://doi.org/10.1080/15298668491399884

Demers PA, Teschke K, Kennedy SM, Leung V (2000) Exposure to dust, resin acids, and monoterpenes in softwood lumber mills. AIHAJ 61(4):521-528. https://doi.org/10.1080/1529866000 8984564

Dennekamp M, Demers PA, Bartlett K, Davies HW, Teschke K (1999) Endotoxin exposure among softwood lumber mill workers in the Canadian province of British Columbia. Ann Agric Environ Med 6(2):141-146

Douwes J, McLean D, van der Maarl E, Heederik D, Pearce N (2000) Worker exposures to airborne dust, endotoxin and beta $(1,3)$ glucan in two New Zealand sawmills. Am J Ind Med 38(4):426430. https://doi.org/10.1002/1097-0274(200010)38:4\%3c426:: aid-ajim8\%3e3.0.co;2-r

Duchaine C, Mériaux A, Thorne PS, Cormier Y (2000) Assessment of particulates and bioaerosols in eastern Canada sawmills. AIHAJ 61(5):727-732. https://doi.org/10.1080/1529866000 8984583

Dutkiewicz J (1976) Studies on endotoxins of Erwinia herbicola and their biological activity. Zbl Bakt Hyg I Abt Orig A 236(4):487-508

Dutkiewicz J, Skórska C, Sitkowska J, Ochalska B, Kaczmarski F (1988) Properties of the endotoxins produced by various gramnegative bacteria present in occupational environments. In: Jacobs RR, Wakelyn PJ, Rylander R, Burrell R (Eds): Cotton dust. 
Proceedings of the 12th Cotton Dust Research Conference and of the Endotoxin Inhalation Workshop, 28-30 September 1987, Clearwater, Florida, pp. 187-189. National Cotton Council, Memphis, Tennessee, 1988

Dutkiewicz J (1989) Bacteria, fungi and endotoxin in stored timber logs and airborne sawdust in Poland. In: O'Rear CE, Llewellyn GC (eds) Biodeterioration research 2: general biodeterioration, degradation, mycotoxins, biotoxins, and wood decay. Plenum Press, New York, pp 533-547

Dutkiewicz J, Olenchock SA, Lewis DM, Ratajczak Z, Kwapiszewski C, Piech T, Bilczuk A (1989) Drill samplers for quantification of microorganisms in wood. For Prod J 39(2):61-65

Dutkiewicz J, Sorenson WG, Lewis DM, Olenchock SA (1992a) Levels of bacteria, fungi and endotoxin in stored timber. Int Biodeterior 30(1):29-46. https://doi.org/10.1016/0964-8305(92)90022-G

Dutkiewicz J, Tucker J, Burrell R, Olenchock SA, Schwegler-Berry D, Keller GE III, Ochalska B, Kaczmarski F, Skórska C (1992b) Ultrastructure of the endotoxin produced by gram-negative bacteria associated with organic dusts. Syst Appl Microbiol 15:474485. https://doi.org/10.1016/S0723-2020(11)80225-0

Dutkiewicz J, Krysińska-Traczyk E, Prażmo Z, Skórska C, Sitkowska J (2001a) Exposure to airborne microorganisms in Polish sawmills. Ann Agric Environ Med 8(1):71-80

Dutkiewicz J, Skórska C, Krysińska-Traczyk E, Dutkiewicz E, Matuszyk A, Sitkowska J (2001b) Response of sawmill workers to work-related airborne allergens. Ann Agric Environ Med $8(1): 81-90$

Dutkiewicz J, Olenchock SA, Krysińska-Traczyk E, Skórska C, Sitkowska J, Prażmo Z (2001c) Exposure to airborne microorganisms in fiberboard and chipboard factories. Ann Agric Environ Med 8(2):191-199

Dutkiewicz J, Skórska C, Burrell R, Szuster-Ciesielska A, Sitkowska J (2005) Immunostimulative effects of repeated inhalation exposure to microvesicle-bound endotoxin of Pantoea agglomerans. Ann Agric Environ Med 12(2):289-294

Dutkiewicz J, Mackiewicz B, Lemieszek MK, Golec M, Milanowski J (2015) Pantoea agglomerans: a mysterious bacterium of evil and good. Part. I. Deleterious effects: dust-borne endotoxins and allergens-focus on cotton dust. Ann Agric Environ Med 22(4):576588. https://doi.org/10.5604/12321966.1185757

Dutkiewicz J, Mackiewicz B, Lemieszek MK, Golec M, Skórska C, Góra-Florek A, Milanowski J (2016a) Pantoea agglomerans: a mysterious bacterium of evil and good. Part. II. Deleterious effects: dust-borne endotoxins and allergens-focus on grain dust, other agricultural dusts and wood dust. Ann Agric Environ Med 23(1):6-29. https://doi.org/10.5604/12321966.1196848

Dutkiewicz J, Mackiewicz B, Lemieszek MK, Golec M, Milanowski J (2016b) Pantoea agglomerans: a mysterious bacterium of evil and good. Part. III. Deleterious effects: infections of humans, animals and plants. Ann Agric Environ Med 23(2):197-205. https://doi. org/10.5604/12321966.1203878

Eduard W, Sandven P, Levy F (1994) Exposure and IgG antibodies to mold spores in wood trimmers: exposure-response relationships with respiratory symptoms. Appl Occup Environ Hyg 9(1):44-48. https://doi.org/10.1080/1047322X.1994.10388263

Færden K, Lund MB, Mogens Aaløkken T, Eduard W, Søstrand P, Langård S, Kongerud J (2014) Hypersensitivity pneumonitis in a cluster of sawmill workers: a 10-year follow-up of exposure, symptoms, and lung function. Int J Occup Environ Health 20(2):167-173. https://doi.org/10.1179/2049396714Y.00000 00063

Fransman W, McLean D, Douwes J, Demers PA, Leung V, Pearce N (2003) Respiratory symptoms and occupational exposures on New Zealand plywood mill workers. Ann Occup Hyg 47(4):287-295. https://doi.org/10.1093/annhyg/meg046
Gioffré A, Marramao A, Iannò A (2012) Airborne microorganisms, endotoxin, and dust concentration in wood factories in Italy. Ann Occup Hyg 56(2):161-169. https://doi.org/10.1093/annhyg/ mer082

Górny RL, Ławniczek-Wałczyk A, Cyprowski M, Gołofit-Szymczak M, Stobnicka A, Bakal A (2017) Wood dust as a source of microbial contamination at joinery. J Int Sci Publ 11:150-164

Górny RL, Gołofit-Szymczak M, Cyprowski M, Stobnicka-Kupiec A (2019) Nasal lavage as analytical tool in assessment of exposure to particulate and microbial aerosols in wood pellet production facilities. Sci Total Environ 697:134018. https://doi.org/10.1016/j. scitotenv.2019.134018

Greaves H (1971) The bacterial factor in wood decay. Wood Sci Technol 5:6-16

Greenberger PA (2019) Hypersensitivity pneumonitis: a fibrosing alveolitis produced by inhalation of diverse antigens. J Allergy Clin Immunol 143(4):1295-1301. https://doi.org/10.1016/j.jaci. 2018.09.040

Harper A, Andrew ME (2006) Airborne endotoxin in woodworking (joinery) shops. J Environ Monit 8(1):73-78. https://doi.org/ 10.1039/b508065g

Health Council of the Netherlands. Dutch Expert Committee on Occupational Standards (2010) Endotoxins: health-based recommended occupational exposure limit. The Hague: Health Council of the Netherlands: Publication no. 2010/04OSH. https://www.healthcouncil.nl/. Accessed 1 June 2021

IARC (International Agency for Research in Cancer) (2016) Wood dust. IARC monographs 100C. IARC, Lyon

Johnston SR, Boddy L, Weightman AJ (2016) Bacteria in decomposing wood and their interactions with wood-decay fungi. FEMS Microbiol Ecol 92:fiw179. https://doi.org/10.1093/femsec/ fiw 179

Kim YS, Choi EJ, Lee WH, Choi SJ, Roh TY, Park J, Jee YK, Zhu Z, Koh YY, Gho YS, Kim YK (2013) Extracellular vesicles, especially derived from gram-negative bacteria, in indoor dust induce neutrophilic pulmonary inflammation associated with both Th1 and Th17 cell responses. Clin Exp Allergy 43(4):443-454. https:// doi.org/10.1111/cea.12085

Krysińska-Traczyk E, Skórska C, Cholewa G, Sitkowska J, Milanowski J, Dutkiewicz J (2002) Exposure to airborne microorganisms in furniture factories. Ann Agric Environ Med 9(1):85-90

Kuś L (1980a) Allergic alveolitis after exposure to antigens occurring in grain dust in the light of own clinical and experimental investigations. Med Wiejska 15:73-80

Kuś L (1980b) Allergic alveolitis after exposure to antigens occurring in grain dust in the light of own clinical and experimental investigations. Dissertation, Medical University of Lublin

Liese W (ed) (1975) Biological transformation of wood by microorganisms. Springer, Berlin

Mackiewicz B, Skórska C, Dutkiewicz J, Michnar M, Malinowski J, Prażmo Z, Krysińska-Traczyk E, Cisak E (1999) Allergic alveolitis due to herb dust exposure. Ann Agric Environ Med 6(2):167-170

Mackiewicz B, Dutkiewicz J, Siwiec J, Kucharczyk T, Siek E, WójcikFatla A, Cholewa G, Cholewa A, Paściak M, Pawlik K, Szponar B, Milanowski J (2019) Acute hypersensitivity pneumonitis in woodworkers caused by inhalation of birch dust contaminated with Pantoea agglomerans and Microbacterium barkeri. Ann Agric Environ Med 26(4):644-655. https://doi.org/10.26444/ aaem/114931

Malmberg P, Rask-Andersen A, Höglund S, Kolmodin-Hedman B, Guernsey JR (1988) Incidence of organic dust toxic syndrome and allergic alveolitis in Swedish farmers. Int Arch Allergy Immunol 87(1):47-54. https://doi.org/10.1159/000234647 
Malmros P, Sigsgaard T, Bach B (1992) Occupational health problems due to garbage sorting. Waste Manage Res 10(3):227-234. https:// doi.org/10.1016/0734-242X(92)90101-P

Mandryk J, Alwis KU, Hocking AD (2000) Effect of personal exposures on pulmonary function and work-related symptoms among sawmill workers. Ann Occup Hyg 44(4):281-289

Milanowski J, Dutkiewicz J, Potoczna H, Kuś L, Urbanowicz B (1998) Allergic alveolitis among agricultural workers in eastern Poland: a study of twenty cases. Ann Agric Environ Med 5(1):31-43

Minárik L, Mayer M, Votrubová V, Ürgeová N, Dutkiewicz J (1983) Exogenous allergic alveolitis caused by hypersensitivity to mouldy beech chips antigens. Description of two cases. Stud Pneumol Phtiseol Cechoslov 43:38-45

Munoz MA, Ahlström C, Rauch BJ, Zadoks RN (2006) Fecal shedding of Klebsiella pneumoniae by dairy cows. J Dairy Sci 89(9):34253430. https://doi.org/10.3168/jds.S0022-0302(06)72379-7

Murdoch CW, Campana RJ (1983) Bacterial species associated with wetwood of elm. Phytopathology 73:1270-1273

Neghab M, Jabari Z, Kargar Shouroki F (2018) Functional disorders of the lung and symptoms of respiratory disease associated with occupational inhalation exposure to wood dust in Iran. Epidemiol Health 40:e2018031. https://doi.org/10.4178/epih.e2018031

NIOSH (National Institute for Occupational Safety and Health) (1987) Health effects of exposure to wood dust. A summary of the literature. U. S. Department of Health and Human Services, NIOSH Publication No. 00174745. https://www.cdc.gov/niosh/docs/ wooddust/default.html. Accessed 1 June 2021

Niemelä SI, Väätänen P, Mentu J, Jokinen A, Jäppinen P, Sillanpää P (1985) Microbial incidence in upper respiratory tract of workers in the paper industry. Appl Environ Microbiol 50(1):163-168

Nogueira R, Melo N, Novais e Bastos H, Martins N, Delgado L, Morais A, Mota PC (2019) Hypersensitivity pneumonitis: antigen diversity and disease implications. Pulmonology 25(2):97-108. https:// doi.org/10.1016/j.pulmoe.2018.07.003

Oppliger A, Rusca S, Charriére N, Vu Duc T, Droz PO (2005) Assessment of bioaerosols and inhalable dust exposure in Swiss sawmills. Ann Occup Hyg 49(5):385-391. https://doi.org/10.1093/ annhyg/meh105

Pepys J, Jenkins PA, Festenstein GN, Gregory PH, Lacey ME, Skinner FA (1963) Farmer's lung: thermophilic actinomycetes as a source of "farmer's lung hay" antigen. Lancet 2:607-611. https://doi.org/ 10.1016/s0140-6736(63)90398-2

Pereira CAC, Gimenez A, Kuranishi L, Storrer K (2016) Chronic hypersensitivity pneumonitis. J Asthma Allergy 9:171-181. https://doi.org/10.2147/JAA.S81540

Pipinić IS, Varnai VM, Beljo Lučić R, Čavlović A, Prester L, Orct T, Macan J (2010) Endotoxin exposure assessment in woodprocessing industry: airborne versus settled dust levels. Arh Hig Rada Toksikol 61:161-166. https://doi.org/10.2478/ 10004-1254-61-2010-1996

Prażmo Z, Krysińska-Traczyk E, Skórska C, Sitkowska J, Cholewa G, Urbanowicz B, Dutkiewicz J (1996) Birch wetwood as a source of potential bacterial hazard for woodworkers. Ann Agric Environ Med 3(1):67-70

Prażmo Z, Dutkiewicz J, Cholewa G (2000) Gram-negative bacteria associated with timber as a potential respiratory hazard for woodworkers. Aerobiologia 16:275-279. https://doi.org/10.1023/A: 1007673107565

Prażmo Z, Dutkiewicz J (2000) Gram-negative bacteria colonizing timber from coniferous and deciduous trees. In; 1st Polish Scientific Conference Deterioration and Corrosion of Technical Materials, Technical University in Łódź, Łodź, Conference Reports. pp 46-48

Prażmo Z, Dutkiewicz J, Skórska C, Sitkowska J, Cholewa G (2003) Exposure to airborne gram-negative bacteria, dust and endotoxin in paper factories. Ann Agric Environ Med 10(1):93-100
Quirce S, Vandenplas O, Campo P, Cruz MJ, de Blay F, Koschel D, Moscato G, Pala G, Raulf M, Sastre J, Siracusa A, Tarlo SM, Walusiak-Skorupa J, Cormier Y (2016) Occupational hypersensitivity pneumonitis: an EAACI position paper. Allergy 71(6):765779. https://doi.org/10.1111/all.12866

Rongo LM, Msamanga GI, Burstyn I, Barten F, Dolmans WM, Heederik D (2004) Exposure to wood dust and endotoxin in small-scale wood industries in Tanzania. J Expo Anal Environ Epidemiol 14(7):544-550. https://doi.org/10.1038/sj.jea.7500375

Rossell SE, Abbot EGM, Levy JM (1973) Bacteria and wood. A review of the literature relating to the presence, action and interaction of bacteria in wood. J Inst Wood Sci 6(2):28-35

Rylander R, Lundholm M (1978) Bacterial contamination of cotton and cotton dust and effects on the lung. Br J Ind Med 35:204-207. https://doi.org/10.1136/oem.35.3.204

Rylander R (1981) Bacterial toxins and etiology of byssinosis. Chest 79(4 Suppl.):34S-38S. https://doi.org/10.1378/chest.79.4_Suppl ement.34S

Rylander R, Thorn J, Attefors R (1999) Airways inflammation among workers in a paper industry. Eur Respir J 13(5):1151-1157. https://doi.org/10.1034/j.1399-3003.1999.13e35.x

Scott ES (1984) Populations of bacteria in poplar stems. Eur J Pathol 14:103-112

Selman M, Pardo A, King TE Jr (2012) Hypersensitivity pneumonitis: insights in diagnosis and pathobiology. Am J Respir Crit Care Med 186(4):314-324. https://doi.org/10.1164/rccm. 201203-0513CI

Sennekamp J, Joest M, Sander I, Engelhart S, Raulf-Heimsoth M (2012) Farmer's lung antigens in Germany. Pneumologie 66(05):297-301. https://doi.org/10.1055/s-0031-1291676

Sforza GGR, Marinou A (2017) Hypersensitivity pneumonitis: a complex lung disease. Clin Mol Allergy 15:6. https://doi.org/10.1186/ s12948-017-0062-7

Shrestha B, Nabin KC, Bastola C, Jahir T, Risal R, Thapa S, Enriquez D, Schmidt F (2021) Pantoea agglomerans: an elusive contributor to chronic obstructive pulmonary disease exacerbation. Cureus 13(10):e18562. https://doi.org/10.7759/cureus. 18562

Siew SS, Martinsen JI, Kjaerheim K, Sparén P, Tryggvadottir L, Weiderpass E, Pukkala E (2017) Occupational exposure to wood dust and risk of nasal and nasopharyngeal cancer: a case-control study among men in four Nordic countries-with an emphasis on nasal adenocarcinoma. Int J Cancer 141(12):2430-2436. https://doi.org/ 10.1002/ijc.31015

Singh AP, Kim YS, Singh T (2016) Bacterial degradation of wood. In: Kim YS, Funada R, Singh AP (eds) Secondary xylem biology. Elsevier, Amsterdam, pp 169-190

Skórska C, Sitkowska J, Burrell R, Szuster-Ciesielska A, Dutkiewicz J (1996) Effects of repeated inhalation exposure to microvesiclebound endotoxin. Ann Agric Environ Med 3(1):61-65

Skórska C, Krysińska-Traczyk E, Milanowski J, Cholewa G, Sitkowska J, Góra A, Dutkiewicz J (2002) Response of furniture factory workers to work-related airborne allergens. Ann Agric Environ Med 9(1):91-97

Straumfors A, Corbin M, McLean D, Mannetje A, Olsen R, Afanou A, Daae H-L, Skare $\varnothing$, Ulvestad B, Johnsen HL, Eduard W, Douwes J (2020) Exposure determinants of wood dust, microbial components, resin acids and terpenes in the saw- and planer mill industry. Ann Work Expo Health 64(3):282-296. https://doi.org/ 10.1093/annweh/wxz096

Towey JW, Sweany HC, Huron WH (1932) Severe bronchial asthma apparently due to fungus spores found in maple bark. JAMA 99:453-458. https://doi.org/10.1001/jama.1932.02740580021005

Tsukioka D, Nishizawa T, Miyase T, Achiwa K, Suda T, Soma G, Mizuno D (1997) Structural characterization of lipid A obtained from Pantoea agglomerans lipopolysaccharide. FEMS Microbiol 
Lett 149(2):239-244. https://doi.org/10.1111/j.1574-6968.1997. tb10335.x

Weber S, Kullman G, Petsonk E, Jones WG, Olenchock S, Sorenson W, Parker J, Marcelo-Baciu R, Frazer D, Castranova V (1993) Organic dust exposures from compost handling: case presentation and respiratory exposure assessment. Am J Ind Med 24(4):365374. https://doi.org/10.1002/ajim.4700240403

Wilhelmsson B, Jernudd Y, Ripe E, Holmberg K (1984) Nasal hypersensitivity in wood furniture workers. An allergological and immunological investigation with special reference to mould and wood. Allergy 39(8):586-595. https://doi.org/10.1111/j.13989995.1984.tb01978.x

Yang J, Kim EK, Park HJ, McDowell A, Kim YK (2020) The impact of bacteria-derived ultrafine dust particles on pulmonary diseases. Exp Mol Med 52:338-347. https://doi.org/10.1038/ s12276-019-0367-3

Zdorovenko EL, Kadykova AA, Shashkov AS, Varbanets LD, Bulyhina TV, Knirel YA (2017) Lipopolysaccharide of Pantoea agglomerans 7969: chemical identification, function and biological activity.
Carbohydr Polym 165:351-358. https://doi.org/10.1016/j.carbp ol.2017.02.053

Zdorovenko EL, Kadykova AA, Shashkov AS, Varbanets LD, Bulyhina TV, Knirel YA (2018) Lipopolysaccharides of Pantoea agglomerans 7604 and 8674 with structurally related O-polysaccharide chains: chemical identification and biological properties. Carbohydr Polym 181:386-393. https://doi.org/10.1016/j.carbpol.2017. 10.087

Zdorovenko EL, Kadykova AA, Shashkov AS, Varbanets LD, Bulyhina TV (2019) Pantoea agglomerans P1a lipopolysaccharide: structure of the O-specific polysaccharide and lipid A and biological activity. Carbohydr Res 484:107767. https://doi.org/10.1016/j. carres.2019.107767

Publisher's Note Springer Nature remains neutral with regard to jurisdictional claims in published maps and institutional affiliations. 